\title{
National System of Germany's Education financing entrances
}

\author{
Mohamed Elasmay Mahrouse \\ Faculty of Education, Sohag University
}

DOI:

\begin{abstract}
Germany has a federal system of government that gives its provinces a high degree of autonomy in education policy, with the Federal Ministry of Education in Berlin playing a role in financing and financial aid and the regulation of vocational education requirements, but most other aspects of education are subject to the authority of the states "Bundesländer". The number of schools in Germany has reached - according to statistics of 2018 - more than 52,400 schools, where more than 12.2 million students learn, and more than 772,600 teachers are working there. From a review of Germany's experiences in financing education, its opportunities, alternatives and requirements for improvement in its educational institutions, we draw the following results:

Education in schools in Germany is free and financed from taxes. As for books and other educational aids, they are loaned to students, and they must return them at the end of the school year, or pay part of their value if they want to keep them. The process of financing education in Germany depends on the states and territories, and some free bodies and capital banks that contribute to the financing process, but in different proportions, and in light of their goals and financial ability, and then the German states are the main source of funding for German education institutions. Companies, factories, and universities in Germany provide technical assistance and finance such as vocational and technical training programs for students in order to prepare students for various jobs, and provide them with skills and practical experiences that help them join the labor market.
\end{abstract}

\section{Introduction}

One of the most complex problems faced by human societies in general is spending on education and its financing gates, The most controversial among them, especially in light of the current global economic conditions, is that there is an unrelenting debate among proponents of various

educational visions on this topic : Some address this issue from a purely economic perspective, calling for the abolition of freebies, and for the student and his family to be charged for their education expenses, Others start with a social platform calling for public spending and expansion 
in educational acceptance to achieve educational democracy and equal opportunities for people of the same homeland. And third, it dominates the cognitive and academic aspects, emphasizing merit and eligibility in admission and mixed financing in spending.

The following article presents National System of Germany's Education and its experience in educational financing.

\section{- National System of Germany's}

\section{Education:}

The history of Germany in the modern era is divided into two main stages: the first stage that lasted from the end of the Second World War in 1945 to 1990 , which is the stage of Germany's division into federal Germany (West Germany), and democratic Germany (East Germany). As for the second stage, it started since the time of the German Union and the achievement of complete unity in 1990 AD. During this period, profound transformations occurred in the education system in Germany, as interest in building additional schools increased in the eastern part of them, and the number of schools in Germany reached. According to the statistics of 2018 , more than 52,400 schools are taught by more than 12.2 million students, and more than 772,600 teachers are educated (Deutsche Schulen, 2018) .

Education is the responsibility of the states and part of their constitutional sovereignty, but state governments coordinate with each other through conferences of the Ministry of Culture in the states. Education in Germany is compulsory, and starts from the age of six until eighteen years, i.e. for a period of 12 years, where students must perform the compulsory general education, which is 9 years, then two years to perform the compulsory vocational education in vocational schools, and education is free in all government schools . As for books and other educational aids, they are loaned to students and they must return it at the end of the school year or pay part of its value if they want to keep it (Bildungs in Deutschland, 2018). Germany has a federal system of government that gives its provinces a high degree of autonomy in education policy, as the Federal Ministry of Education in Berlin plays a role in financing and financial aid and organizing the requirements for vocational education and entry into professions, but most other aspects of education are subject to the authority of individual states or "Bundesländer" (Bildungs in Deutschland, 2018)

This is for each of the sixteen states in Germany a minister responsible for education and educational policy, which stems from the federal (federal) principle that stipulates the distribution of powers between the federal government and the sixteen states and giving these states powers to oversee education matters. The federal government's mission is focused on legislative, financial, and educational planning, as the German Federal 
Constitution emphasizes the need for cooperation between the Federal Government and German states in the field of education (Bildungs in Deutschland, 2018).

In general, the education system in Germany (Bildungs system in Deutschland 2018) is divided into five levels: the primary level (die Primarstufe), the secondary level 1 die Sekundarstufe I), and the secondary level 2 (Sekundarstufe II) which is qualified for technical and vocational colleges, then Level 4 (der quartäre Bereich) - Higher education level / Der tertiäre Bildungsbereich (German School System, 2019).

Compulsory education begins in Germany at the age of six, and continues in most states for a period of nine years, and this stage of primary education is a unified stage among all German provinces in all aspects of German education, where all students study in the same school from grade 1 to 4 , and where all go German students almost go to "Grundschule" (foundation school), where they study the same basic general subjects, and at the end of this foundation course, students move to different types of high school (German School System, 2019).

Parents in most states can choose to either send their children to secondary schools in a career path, or enroll them in middle schools and in some states. School recommendations affect tracking and in other states, assignments are mandatory based on the average grade of grade during academic observation in grades 5, 6 German School System (Thomas, 2017).

In Germany, the rules regarding the school education system differ from state to state. The reason for this is that education in Germany is one of the tasks of the ministries of education of the federal states, and this means that the federal states are responsible for amending the rules of their educational system. After the end of the kindergarten, which is an optional stage in Germany, compulsory school education begins, as compulsory school education laws differ from one German state to another, but this stage often begins when the child reaches his sixth year, and ends when he is at the age of eight Ten, and it should be noted that primary schools in Germany are free and tax-funded (Thomas, 2017). After the primary education stage (die Primarstufe) ends, the children move to the complementary schools (Die Sekundarstufe I), which depends primarily on the results of the children in the primary stage, their competence and their ability to learn. The teachers provide suggestions to the parents that help them choose the appropriate school for their children, knowing that in the primary stage the students are accompanied during the four years with the teacher or teacher, which allows them to follow the development of the students and helps them to assess their ability well during the primary stage . At this stage, students can obtain three different certificates. 
The first is the Hauptschulabschluss Basic Education Certificate, which is the regular certificate obtained at the end of this school. It is also possible for students of this school, optionally and after the ninth grade, to transfer to the Berufsfachschule vocational school or to the preparatory year for the profession Berufvorbereitungsjahr, which is denoted by abbreviation $\mathrm{BVJ}$ or to the education provided by the duall Bildung in one of the institutions, and after the end of this year they can submit an exam that allows them to obtain A qualifying basic education certificate. They can also optionally join the tenth grade, by moving them from basic school to the practical middle school, Realschule, to obtain what is known as an intermediate education certificate, knowing that each of the federal states has its own laws and regulations regarding school certificates issued by basic schools. As for the Realschule middle school, it continues until the tenth grade. The certificate that students receive at the end of this stage is called the intermediate education certificate. After obtaining this certificate, students have four options, namely, to transfer to Gymnasium High School, which depends on the results of the middle school student. The Students can also transfer to the Fachhochschule Higher Specialized School or the Berufvorbereitungsjahr (Professional Vocational School ) or to the duall Bildung dual education, or to the basic professional school year
Berufgrundschuljahr which is denoted by the abbreviation (BGJ), and this means that who gets a basic education certificate Hauptschulabschluss or certificate Intermediate education Mittelschulabschluss, they cannot go to universities, but can start with vocational training or enroll in vocational schools (Bildung in Deutschland, 2012).

As for Gymnasium high school, it is intended for those who enjoy very good educational competencies and its marks are also good, and the attendance in high schools is often longer than the rest of the schools, and education is deep and broad, unlike other schools. In addition, high school allows learning at least two foreign languages. Study continues in this school until the twelfth or thirteenth grade, depending on the state, and in the end the student gets a high school diploma Abitur, which allows in the end to continue studying in German universities or higher institutes there (Bildung in Deutschland, 2012).

Perhaps the most important characteristic of the education system in Germany is the constant stimulation of learning, as there are many students who need special educational support, which he cannot get in regular primary schools Grundschule, and her parents can enroll their children in schools supporting them known as Förderschulen.

In supplementary schools, some students drop out of school before obtaining school certificates allowing them to conduct vocational training or 
learn at university. These people allow the education system in Germany to continue their education later, even if they are old, as in Germany there is what is known as night supplementary schools and it allows them to obtain a basic education certificate Hauptschulabschluss or even an Abitur certificate, and this of course is what allows them to continue their studies In higher institutes or universities and thus improve their job opportunities (Christine \& Karl, 2014) .

\section{- Financing entries for education in}

\section{Germany}

The management and financing of Germany's Education is a joint responsibility of the state (The federal government). The German constitution defines the responsibility of the federal government in setting a general framework for higher education policy (General principles of higher education), while leaving the responsibility of each state to implement this policy, and those principles and the provision of educational services within its borders according to their circumstances and in line with the local demands and needs of each state or province (Ellger, 1996) .

Education funding in Germany is distributed between the federal government and the states and between the municipalities of cities and villages, and the states pay salaries and expenses for teachers and workers, as well as municipalities, knowing that the funding system is based on clear foundations that the state may not impose any financial fees on students of public schools, It is also necessary for all states to provide educational materials to students free of charge, in addition to allocating cars to transport students to and from school. Thus, the process of financing education in Germany depends on the states and territories, and some free bodies, in addition to the contributions of capital banks that contribute to the financing process, but in different proportions, and in light of their goals and financial ability (Ellger, 1996).

Thus, the states, regions, and local German authorities, and some of the German private bodies, contribute to the financing of education in various proportions. In light of the circumstances of each state, the percentage of what families, families, and members of the local community spend in support of educational activities in schools. The German states are the main source of funding for German education institutions, it is the states that provide these institutions with the necessary funding so that they can assume the roles assigned to them, and the states through the ministries concerned with them are mainly responsible for deciding how to allocate financial funds fairly to institutions The different education according to the needs of each institution, The companies and factories, in cooperation with colleges and universities, provide technical assistance such as vocational and technical training programs for students in order to prepare students for various jobs, and provide them 
with skills and practical experiences that help them join the labor market.

The federal government also provides about $7 \%$ of the total spending on education, while the states provide about $32 \%$, and the local authorities bear the rest of the education expenses that reach approximately $23 \%$, in addition to public funds, and the aid suspended by civil societies, societies, and scientific clubs ( Karpen, 2006 ).

A few years ago, a trend appeared in the German education system to reduce support for private schools there, and strong opposition to this trend emerged, as explained by (Lüdecke, 2014) in his presentation of public discussions about the questions of opponents : Why do private schools have to be supported with less money than government support directed to public schools and because it is planned to reduce government support for them, as independent schools are structurally adapted to the government school system, here too, subsidies directed to private primary and secondary schools are canceled Achieving the merger stipulated in the law. This is the only reason the amendment is necessary. But there will also be a financial change. On average, private schools receive the value of government funding in support of their educational activities at rates less than (2\%) than those in government schools.

In Germany there are independent schools (Unabhängige Schulen in Deutschland), but these schools are not created by the state, as they can be organized by private companies, churches, or charities spread in Germany, and often these independent schools have a distinct concept, teaching methods of their own, and these independent schools often require their students to pay additional tuition fees, in addition to funding support from the governments of the German federal states (Bildungssystem und Schulsystem in Deutschland, 2019).

\section{- Conclusion on Germany's experience in education financing:}

From a review of Germany's experiences in financing education: its opportunities, alternatives and requirements for improvement in its educational institutions, we draw the following results:

- Education in schools in Germany is free and financed from taxes. As for books and other educational aids, they are loaned to students and they must return it at the end of the school year, or pay part of its value if they want to keep it.

- The most important characteristic of the education system in Germany is the constant stimulation of learning, as there are many students who need special educational support, provided for free through close cooperation with the colleges of education there. 
- German higher education administration and financing is a shared responsibility of the Federal Government and the German states. The German constitution defines the responsibility of the federal government in setting a general framework for higher education policy while leaving the responsibility of each state to implement this policy, and those principles and the provision of educational services within its borders according to their circumstances and in line with the local demands and needs of each state or province.

- The process of financing education in Germany depends on the states and territories, and some free bodies and capital banks that contribute to the financing process, but in different proportions, and in light of their goals and financial ability, and then the German states are the main source of funding for German education institutions.

- Companies, factories, and universities in Germany provide technical assistance and finance such as vocational and technical training programs for students in order to prepare students for various jobs, and provide them with skills and practical experiences that help them join the labor market.

- The federal government provides support in the area of education spending, and the local authorities bear the rest of the education expenses, in addition to funds, aid suspended by civil societies, societies, scientific clubs, and bank donations there.

\section{Conclusion}

In the Guide of Germany's financing education: its opportunities and alternatives in educational institutions it can be benefiting from them by identifying the most important alternatives to support financing in the various educational institutions, which are derived from this experience, such as:

1. Participation of the private and nongovernmental economic sectors in supporting educational financing in schools.

2. Participation of public and private universities in enriching educational activities in educational institutions.

3. The role of colleges of education in developing professional levels and raising competencies and competencies among teachers.

4. Participation of non-governmental community institutions in achieving efficiency and effectiveness in the educational process.

5. The role of national and private banks and the stock market in the financial flow for the conduct of education work.

6. Participation of families, and members of the local community, and taxation to support the costs of education. 
7. Determine the mechanisms for rationalizing spending and reducing the cost of conducting education work while ensuring quality in it.

These alternatives to educational financing, drawn from the German experience, can be used to suggest contemporary visions of educational financing.

\section{References}

Bildung in Deutschland, (2018). Ein indikatorengestützter Bericht mit einer Analyse zu Bildung und Migration. Konsortium Bildungsbericht - erstattung Im Auftrag der Ständigen Konferenz der Kultusminister der Länder in der Bundesrepublik Deutschland und des Bundesministeriums für Bildung und Forschung.

Bildung in Deutschland, (2012). www.destatis. de/DE/ Startseite. html.

Bildungssystem in Deutschland, (2018). https://www.profiling-institut.de/bildungssystem-indeutschland.

Bildungssystem und Schulsystem in Deutschland, (2019).

https://de.wikipedia.org/wiki/Bildungssystem.

Christine . E \& Karl .B., (2014). Deutschland, deine Lehrer: Warum sich die Zukunft unserer Kinder im Klassenzimmer. http://www.amazon.de.
Deutsche Schulen, (2018). Anzahl der Schulen in Deutschland.

https://www.datendieter.de/item/Deutsche Schulen? gclid=Cj0KCQjw7YblBRDFARIsAKkKdJdZ2QSZ30S8mUa4bNpFeFzRKXAc0 vuTPbSelXQveZMhohCAr8mGZQaApeAEALw w cB.

Ellger, R., (1996). Country Briefing, special Education in Germany. European journal of special Needs Education. vol . 10 . No 1 . p. 77.

German School System.

(2019).

https://www.howtogermany.Com/

pages/germanschools.html.

Karpen, U., (2006). Organization and Procedures for funding higher education in the Federal Republic of Germany. Higher Education in Europe, volx.No. 1, pp. 297-304 .

Lüdecke, M, (2014). $\quad$ www.destatis. de/DE/Publikationen/Thematisch/BildungForschung Kultur/BildungKulturFinanzen/SchulenfreieTraeger 5217110099004.pdf?blob=publicationFile

Thomas, E. (2017). Bildungswesen in der Bundesrepublik Deutschland 2015/2016, Sekretariat der Ständigen Konferenz der Kultusminister der Länder in der Bundesrepublik Deutschland, Taubenstr. 10, 10117 Berlin. 